\title{
ПЕШЕХОДНЫЙ РОБОТ
}

\author{
Василий Шуть \\ Брестский государственный технический университет, \\ ул. Московская 267, 224017 Брест, Беларусь \\ lucking@mail.ru
}

\begin{abstract}
Резюме: Анализируется основной недостаток пешеходных переходов, а именно, прерывание потока автотранспортных средств, движущихся по магистрали. Приводится расчет экономических потерь $в$ конфликте пешеход-автомобиль на регулируемом пешеходном переходе. Предлагается кардинальное решение этой проблемы путем установки магистральных систем “Пешеходный робот”, который быстро и безопасно перемещает пемеходов на противоположную сторону магистрали с минимальным прерыванием транспортного потока магистрали.
\end{abstract}

Ключевые слова: автотранспортные средства, светофорное регулирование, пешеходный переход, робот, электромобиль, магистраль.

\section{PEDESTRIAN ROBOT}

\author{
Vasilij Shut' \\ Brest State Technical University, \\ Moskovskaja str., 267, 224017 Brest, Belarus, \\ lucking@mail.ru
}

\begin{abstract}
In the paper there are analyzes the major drawback of pedestrian crossings, namely, interruption of vehicles moving flow on the highway. It is given a calculation of economic losses in the conflict "pedestrian-vehicle" on a controlled pedestrian crossing. It is proposed a radical solution of this problem by setting the bus system "Walking Robot", which quickly and safely move pedestrians to the opposite side of the highway with minimal disruption of a highway traffic flow.
\end{abstract}

Keywords: Motor vehicles, traffic light regulation, crosswalk, robot, electric car, arterial highway.

\section{ВВЕДЕНИЕ}

Всё в больших объемах и в самых разнообразных качествах роботы входят в нашу действительность: быт, производство и т.д. Используются роботы и в управлении дорожным движением автотранспорта [1]. Эти специализированные роботы совершают одну и ту же операцию изо дня в день.

В настоящей работе предлагается еще один тип роботов - пешеходных, работающих на пешеходных переходах и выполняющих набор циклических операций по быстрому и безопасному перемещению пешеходов через широкую с интенсивным движением автотранспортных средств магистраль.

\section{1. ПОСТАНОВКА ЗАДАЧИ}

Совсем недавно проблемы координации и управления транспортными потоками на уличнодорожных сетях (УДС) не были столь актуальными. В условиях не слишком высоких загрузок УДС функционировали достаточно эффективно, и их деятельность не приводила к серьезным перебоям и отказам в обслуживании. В последние годы рост уровня автомобилизации и транспортной подвижности населения привел к насыщению городских улиц, что явилось причиной переоценки принципов управления транспортными потоками [2].

Статистические данные интенсивности движения на магистральных улицах США и Европы свидетельствуют о том, что именно на 
магистралях сосредотачиваются основные транспортные потоки, другими словами, выполняется принцип “концепции концентрации" [3], что вызывает в последнее время существенный интерес к совершенствованию управления транспортными потоками на городских дорогах и магистральных улицах. Ежегодное увеличение транспортной нагрузки на основные магистрали приводит к устойчивому снижению скорости движения транспортного потока и образованию заторовых ситуаций.

Применение светофорной сигнализации дает возможность обеспечить поочерёдный пропуск транспортных средств и пешеходов. Как правило, режим светофорного регулирования рассчитывается исходя из объемов конфликтующих транспортных потоков, а затем проверяется на удовлетворение потребностей пешеходного движения.

Время, необходимое для пропуска пешеходов по какому-то определённому направлению, рассчитывается по эмпирической формуле [4], получивший широкое распространение в мировой практике и учитывающей суммарные затраты времени на пропуск пешеходов,

$$
\mathrm{t}_{\text {пш }}=5+\mathrm{B} / \mathrm{V}_{\text {пш }}
$$

где $\mathrm{t}_{\text {пш }}$ - длительность такта регулирования, обеспечивающего пропуск пешеходов, В - длина перехода до противоположного тротуара или островка безопасности, $\mathrm{V}_{\text {пш }}$ - скорость движения пешеходов (обычно принимается равной $1.3 \mathrm{~m} / \mathrm{c}$ ).

Так для регулируемого пешеходного перехода с длиной $\mathrm{L}=32$ метра необходимо, согласно формуле (1), не менее чем на 25 секунд прервать движение автотранспортных средств (АТС) по магистрали. Такая вынужденная остановка интенсивного потока, движущегося по магистрали, помимо временных потерь несет повышенный износ резины, моторесурса, потерю горючего, ухудшает экологию города. Необходимо иметь систему технических средств, встроенных в магистраль, которые исключили бы, либо свели к минимуму остановку АТС и связанные с этим потери.

\section{2. ЭКОНОМИЧЕСКИЕ ПОТЕРИ ОТ ПРЕРЫВАНИЯ ТРАНСПОРТНОГО ПОТОКА}

Очевидным моментом в конфликте пешехода с АТС является экономический фактор. Такая резкая остановка АТС перед пешеходным переходом ведет к потере топлива, эквивалентного той кинетической энергии, которую имели АТС до остановки.
Пусть пачка АТС состоит из следующих автомобилей: 16 - легковых автомобилей, 3 грузовых, 2 автобуса. После остановки на перекрестке пачка автомобилей должна восстановить свою прежнюю скорость 60 км/ч и, следовательно, прежнюю кинетическую энергию:

$$
\mathrm{w}=\mathrm{mv}^{2} / 2 \text {. }
$$

Для расчета кинетической энергии выберем следующие типовые массы транспортных средств из [5]:

- легковой автомобиль (в среднем по ВАЗ2108) - 1450 кг;

- грузовой автомобиль (в среднем по ГАЗ5312) - 7850 кг;

- автобус (в среднем по ЛиА3-677М) 16133 кг.

Следовательно, общая масса пачки составляет $1450 * 16+7850 * 3++16133 * 2=79016$ кг.

Необходимая энергия для разгона до первоначальной скорости перед перекрестком будет $\mathrm{W}=79016 * * 16 * 16 / 2=10,91 \mathrm{MД}$. Количество топлива, затраченного на разгон, можно определить, поделив количество найденной энергии на удельную теплоту сгорания топлива (бензина). Удельная теплота сгорания бензина равна 47 МДж/кг.

Итак, количество потерянного топлива составляет $10.91 / 47=0,23(\kappa г)$. Так как КПД двигателя внутреннего сгорания равен 25\%, то для разгона потребуется в четыре раза больше топлива, а именно, 0,92 кг или 1,31 л.

Из приведенного расчета следует, что на каждом цикле работы светофора в среднем теряется 1,3 литра топлива. Длительность цикла светофорного объекта в среднем равна 1,5 мин., следовательно, за час перерасход топлива составляет 52,4 литра.

Не только на перегоне магистрали, но и на перекрестке пешеходные потоки являются существенной помехой для лево- (право-) стороннего транспорта. В результате недостаточной длительности зеленой фазы светофора и большого числа лево- (право-) стороннего транспорта из этих АТС создаются заторы. Таким образом, доля вклада пешеходов в создании заторовых ситуаций составляет не менее $1 / 3$.

На настоящий момент известно два варианта устранения пешеходов как помехи для АТС. Оба варианта предполагают вынесение пешеходных переходов над или под магистраль. Первый вариант портит архитектурный вид города и мешает троллейбусным линиям. Второй вариант очень дорогостоящий. В настоящей работе 
предлагается кардинальное решение проблемы пешеходов в дорожном движении (ДД), позволяющее почти полностью исключить их из ДД.

Для этого предлагается организовать своеобразный лифт через дорогу. Идея лифта давно и широко используется не только в быту, но и на производстве, к примеру, шахтные лифты, и т.д. Везде, где необходимо облегчить физические нагрузки, либо обезопасить определенный процесс, используются лифты.

В данном случае переход через широкую, интенсивно-насыщенную движением автомобилей магистраль является таким случаем. Помимо безопасного перемещения пешеходов через магистраль такой лифт обеспечивает и минимальное время прерывания интенсивного транспортного потока, что является экономически и экологически выгодным в условиях города.

\section{3. МАГИСТРАЛЬНАЯ СИСТЕМА "ПЕШЕХОДНЫЙ РОБОТ"}

Пешеходов необходимо переместить из точки $\mathrm{N}$ в точку K (Рис. 1), таким образом, чтобы не повлиять на транспортный поток магистрали. В теории информации для передачи большого объема данных их уплотняют, затем капсулируют и передают. Аналогичный механизм приложим и к пешеходам, которых необходимо компактно сгруппировать (капсулировать) и быстро переместить из точки $\mathrm{N}$ в точку К. Для этих целей предлагается мобильный пешеходный робот (рис. 2), включенный в контур системы управления транспортными потоками УДС города.

Мобильный пешеходный робот является низкоплатформенным электромобилем без водителя, достаточной вместимости, стоящих и держащихся за поручни пассажиров (пешеходов), которым необходимо пересечь магистраль (рис. 2). Управление роботом выполняется внутренним, встроенным компьютером.

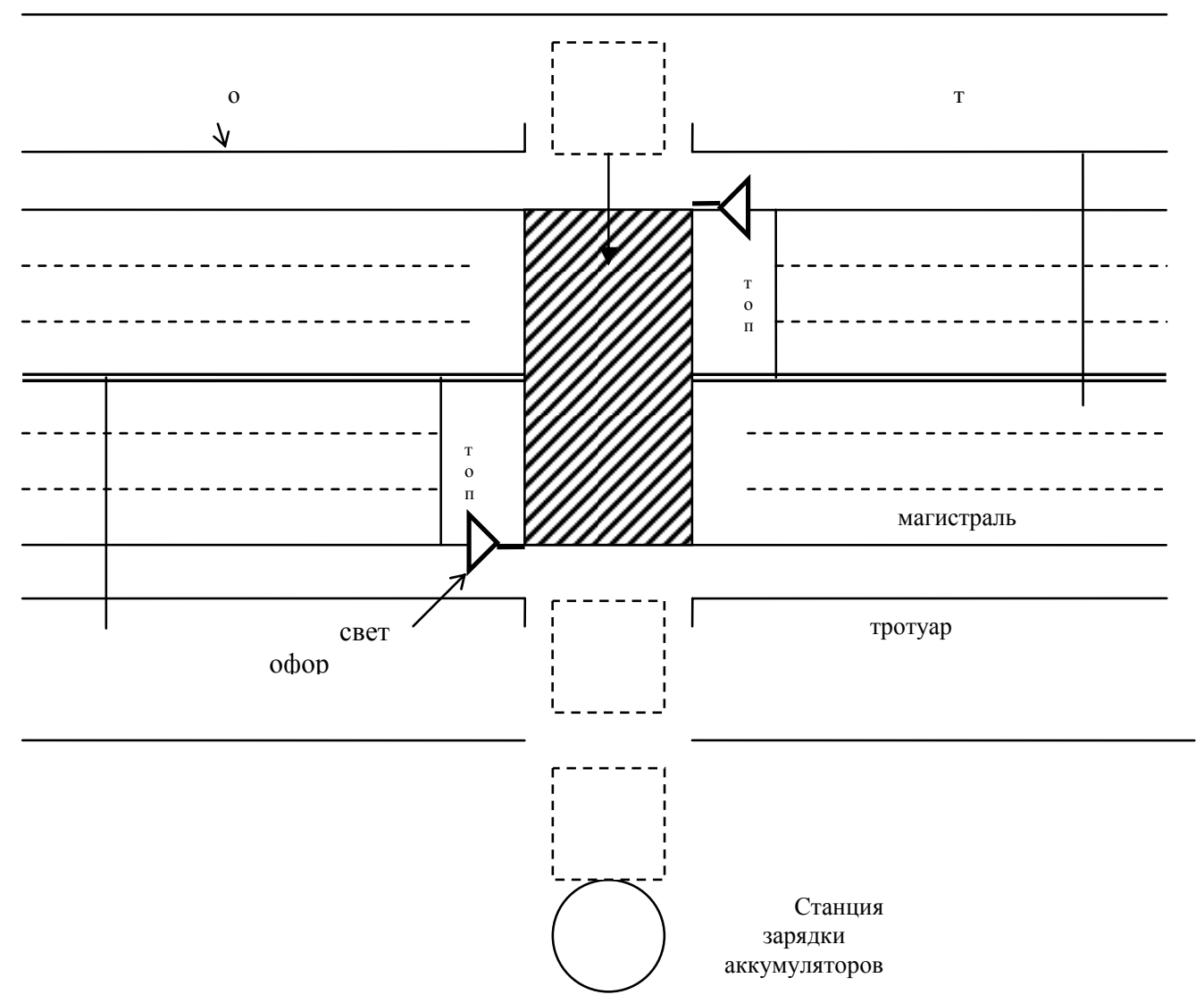

Рис. 1 - Пешеходный переход на перегоне магистрали 


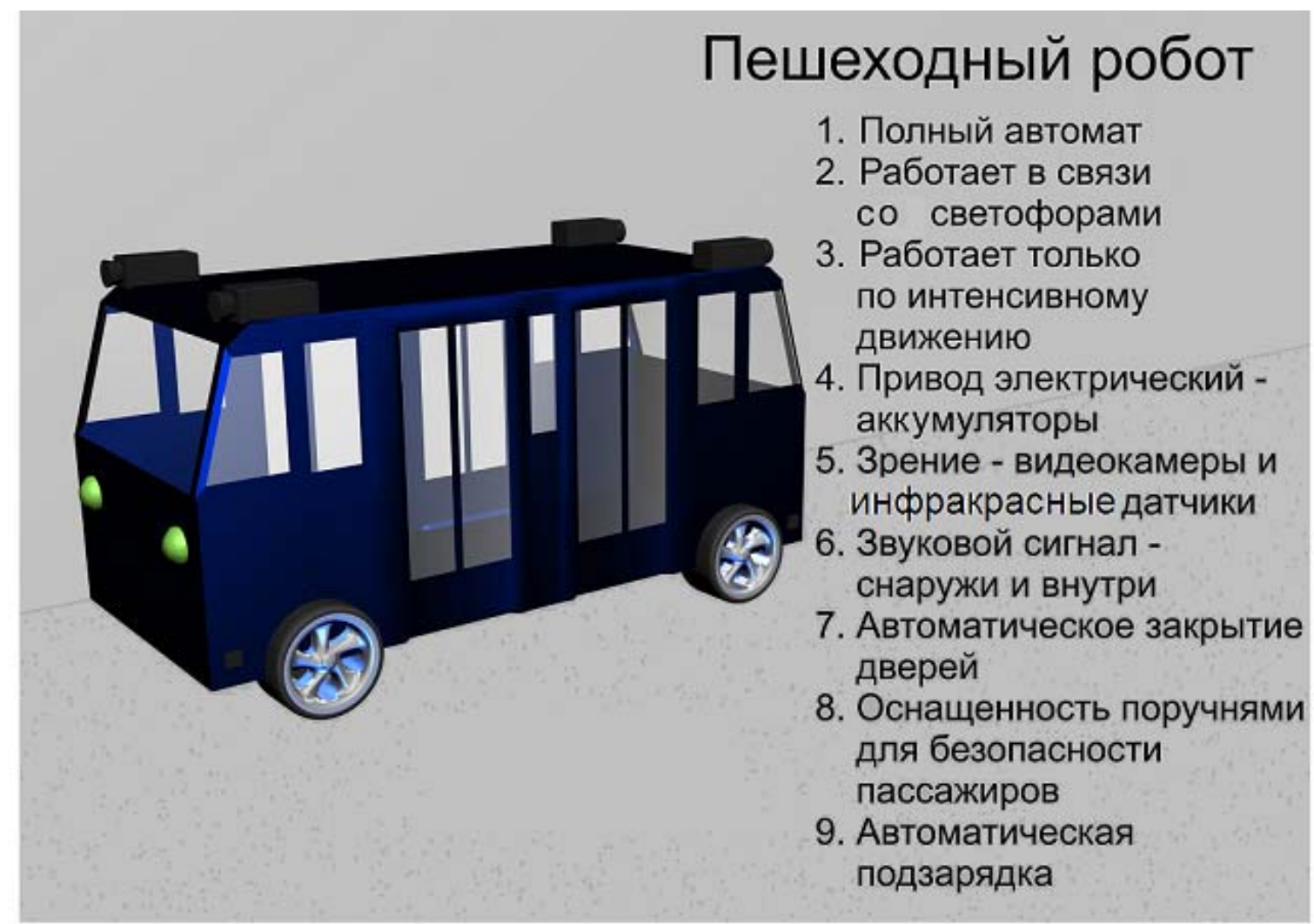

Рис. 2 - Электромобиль системы "Пешеходный робот"

Загрузка салона электромобиля производится на позициях 1 и 2 (рис. 1). В это время двери открыты и пешеходы заходят в салон. Для определения количества людей в электромобиле используются видеокамеры с соответствующим программным обеспечением. Таким образом можно судить о количестве пассажиров в салоне электромобиля. Если пассажиров нет, то нет необходимости начала движения, даже если от системы контроля транспортных потоков пришел сигнал, разрешающий начало движения.

Заполнение салона электромобиля выполняется в течении действия зеленой фазы светофора по магистрали. Закрытие дверей электромобиля осуществляется при одновременном истечении времени $t_{\min }$ движения по магистрали (минимальная длительность основного тракта) и отсутствия входящих пешеходов в электромобиль от датчиков дверей. Теперь электромобиль готов к движению. Сигнал на начало движения должен поступить с детекторов транспорта, расположенных в сечении А и В магистрали (рис. 1). Эти сечения А и В отнесены от границ пешеходного перехода A ' и B $^{\prime}$ на расстояние $100 \mathrm{M}$, которое транспортное средство, двигающееся со скоростью v=60 км/час преодолевает за 6 секунд.

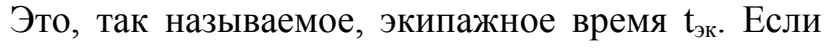
над линией $\mathrm{A}(\mathrm{B})$ не появляется очередной автомобиль через время равное $\mathrm{t}_{э к}$, то следовательно, в транспортном потоке произошел разрыв, не меньший по длительности, чем $t_{э к}$. Таким образом в промежутках магистрали $\mathrm{AA}^{\prime}$ и $\mathrm{BB}^{\prime}$ автомобилей нет и электромобиль может начать движение, не оказывая помех АТC магистрали.

При этом для АТС магистрали загорается красный сигнал светофора, а для электромобиля - зеленый. При средней скорости движения электромобиля 40 км/час он преодолеет пешеходный переход в 30 метров за 3 секунды. Как только он окажется в положении 2 сразу изменятся сигналы светофора. Транспортировка пешеходов выполнена без остановки АТC магистрали. Аналогичным образом выполняется перемещение пешеходов из положения 2 в положение 1 (рис.1).

Электромобиль курсирует по пешеходному переходу не постоянно. Детекторы транспорта в сечениях А и В измеряют интенсивность транспортного потока и при падении ее ниже заданной величины M1 электромобиль переезжает в позицию 3 (рис. 1). В этом случае пешеходный переход используется традиционным способом. При увеличении интенсивности до величины М2 (M2>M1) и сохранении этой величины в течении некоторого заданного времени $t_{3}$ электромобиль выезжает на позицию 2 для очередной загрузки пешеходов.

В позиции 3 электромобиль находится также 
в ночное время. В это время он подключается к станции зарядки аккумуляторов.

В настоящее время проведено компьютерное моделирование системы "Пешеходный робот" в различных режимах интенсивности транспортных потоков и пешеходов, а также выполнен рабочий макет действующей системы в рамках проекта с предприятием Белкоммунмаш (производитель трамвайно-троллейбусной техники в Республике Беларусь).

\section{Выводы}

Предложен эффективный способ беспрепятственного проезда АТС через регулируемые пешеходные переходы, а также через светофорные перекрестки, где будет отсутствовать такая помеха, как пешеход. Окупаемость системы составляет 3-6 месяцев в зависимости от места установки.

\section{ЛИТЕРАТУРА}

[1] V.A. Golovko, L.P. Matyshkov, V.N. Shuts, Principles of Artificial Intelligence, Brest: BSTU, 2010, 112 p. (in Russian)

[2] A.Yu. Mikhailov, I.M. Golovhykh, Modern Tendencies for Design and Reconstruction of
Street-Road Networks, Novosibisk: Nauka, 2004, 266 p. (in Russian)

[3] http://www.fhwa.dot.gov - U.S. Departament of Transportation: Federal Highway Administration (FHWA).

[4] Yu.A. Kremenets, M.P. Pecherskiy, Technical Tools for Traffic Regulation, Moscow: Transport, 1981, 256 p. (in Russian)

[5] V.N. Lukanin, A.P. Buslayev, M.V. Yanshyna, Motor Transport Streams and the Environment, Moscow: Infra-M, 2001, 644 p. (in Russian)

Шуть Василий Николаевич - кандидат технических наук, доцент каффедры "Интеллектуальные информационные технологии" Брестского государственного технического университета. Автор 150 научных работ u одной монографии. Специалист в области технической диагностики ЭВМ, моделирования транспортных потоков, адаптивного управления автотранспортом, прикладной теории графов. Внедрил в серийное производство три прибора технической диагностики, а так же систему адаптивного управления светофорными объектами в 2. Бресте (АСУА - Брест 1). Имеет звание "Изобретатель СССР". 


\title{
PEDESTRIAN ROBOT
}

\author{
Vasilij Shut' \\ Brest State Technical University, \\ Moskovskaja str., 267, 224017 Brest, Belarus, \\ lucking@mail.ru
}

\begin{abstract}
In the paper there are analyzes the major drawback of pedestrian crossings, namely, interruption of vehicles moving flow on the highway. It is given a calculation of economic losses in the conflict "pedestrian-vehicle" on a controlled pedestrian crossing. It is proposed a radical solution of this problem by setting the bus system "Walking Robot", which quickly and safely move pedestrians to the opposite side of the highway with minimal disruption of a highway traffic flow.
\end{abstract}

Keywords: Motor vehicles, traffic light regulation, crosswalk, robot, electric car, arterial highway.

\section{INTRODUCTION}

All in large quantities and in a variety of qualities of the robots are our reality: art, life, production, etc. Robots are ideal for a monotone, monotonous work. The speed of their work earlier, they are less expensive workers - the people and not subject to fatigue. In this paper we propose another type of robots - walking, working at pedestrian crossings and perform a set of cyclic operations.

Statistical data traffic on the main streets of the United States and Europe indicate that it is the major focus on highways traffic flows, in other words, the principle holds: the concept of concentration, which is the last time a significant interest in improving traffic management in urban roads and main streets. The annual increase in traffic load on the main highway leading to the steady drop in the rate of traffic flow and the formation of traffic jam situations.

\section{PROBLEM DEFINITION}

The use of traffic light signal gives an opportunity to provide alternate passage of vehicles and pedestrians. As a rule, the regime of traffic light control is calculated based on the volume of conflicting traffic flows, and then checked on the needs of pedestrians.

The obvious point in the conflict with pedestrian ATS is an economic factor. So abruptly stopping ATS before the crossing leads to a loss of fuel, the equivalent of the kinetic energy, which had a PBX to a stop.
Not only on the stretch line, but also at the crossroads of pedestrian flows are significant hindrances to the left (right) side of the transport. As a result of insufficient duration of green phase of traffic lights and a large number of left (right) side of the transport of these exchanges are created congestion. Thus, the percentage contribution of pedestrians in the creation of traffic jam situations is no less than $1 / 3$.

At present we know two options for addressing pedestrians as obstacles for ATS. Both options imply a pedestrian crossing over or under the highway. The first version of the spoils architectural views of the city and prevents trolley bus lines. The second option is very expensive, we propose a radical solution to the problem of pedestrian traffic (DD), which allows almost completely excluded from the DD.

\section{HIGHWAY SYSTEM "PEDESTRIAN ROBOT"}

Pedestrians to move from point $\mathrm{N}$ to point $\mathrm{K}$, so as to not affect traffic flow on highways. In information theory, to transfer large amounts of data they condense, and then encapsulated and transmitted. A similar mechanism to attach and to pedestrians who need a compact group (encapsulate) and quickly move from point $\mathrm{N}$ to point K. Proposed for this purpose mobile walking robot, included in the outline of traffic control UDS city.

Mobile robot is walking low-platform electric vehicles without a driver, of sufficient capacity, standing and holding on to rail passengers. 
Controlling the robot holds an internal, built-in computer.

\section{CONCLUSION}

An effective way to travel unhindered through the ATC controlled pedestrian crossings, as well as through the traffic lights, where there will be no such interference, as a pedestrian. Payback system is 3-6 months depending on location.

Currently, a computer simulation system "Pedestrian Robot" in various modes of the intensity of traffic and pedestrians, and made a working model of the existing system. The author directs a joint development project with such a reputable company like Belkommunmash (producer of Tramtrolleybus vehicles in the Republic of Belarus).

\section{REFERENCES}

[1] V.A. Golovko, L.P. Matyshkov, V.N. Shuts, Principles of Artificial Intelligence, Brest: BSTU, 2010, 112 p. (in Russian)

[2] A.Yu. Mikhailov, I.M. Golovhykh, Modern Tendencies for Design and Reconstruction of Street-Road Networks, Novosibisk: Nauka, 2004, 266 p. (in Russian)

[3] http://www.fhwa.dot.gov - U.S. Departament of Transportation: Federal Highway Administration (FHWA).

[4] Yu.A. Kremenets, M.P. Pecherskiy, Technical Tools for Traffic Regulation, Moscow: Transport, 1981, 256 p. (in Russian)

[5] V.N. Lukanin, A.P. Buslayev, M.V. Yanshyna, Motor Transport Streams and the Environment, Moscow: Infra-M, 2001, 644 p. (in Russian) 